\title{
Workers' Participations in the Management of H.P. State Electricity Board
}

\author{
Parkash Chandel \\ Department of Commerce, H.P.U. Centre for Evening Studies, Shimla (Himachal-Pradesh), India \\ chandelparkash@gmail.com
}

\begin{abstract}
Participative management recognizes the desire of the workers for a say, an involvement and control over and understanding of the decisions which affects their lives. Workers' participation in management which meet the aspirations of the workmen and have recently emerged are respectively the whitely type councils, profit-sharing plans and co-partnership, and worker-director schemes, sharing of information with, and consulting, workers to sharing the right of decision-making on issues of interest to the working class. Whatever may be the form of control there is inevitably some flow of power and authority from management to workers.
\end{abstract}

Key Words: Profit-sharing plans, Co-partnership, Workers-director schemes, Involvement of workers, Industrial democracy, Developing and effectively utilizing human talent, corporate objective.

\section{Introduction}

Workers' participation in management is involvement of workers only in such areas of activities of the enterprise where they can make some positive contribution for the betterment of an enterprise. Such participation should facilitate effective utilization of available resources and execution of long term expansion plans, including diversification. It should facilitate the day to day functioning as well as inventions and innovations. It is a principle of attaining industrial democracy by ensuring the total involvement of the workers in achieving the organizational goals of the enterprise. The participation results from practices which increases the scope for employees' share of influence in decision making at different tiers of the organization hierarchy with concomitant assumption of responsibility and the participation of each employee should strictly confine to the field for which he is competent and concerned with. This is possible only when both workers and the management commit themselves to the organization. Hence, the success of workers' participation largely depends upon mutual understanding, faith and trust (Micheal, 1991).

Participation and involvement of workers in the management of industry or organization is practiced in most of the countries of the world. Workers' participation in management is an overworked concept in business and government and an underworked activity. The concept of workers participation in management crystallizes the concept of industrial democracy, and indicates an attempt on the part of the employer to build his employees into a team which works towards the realization of common objectives. It has a unique motivational power and great psychological value. Workers' participation in management aids two way communication which results in better flow of ideas and opinions. This helps the management to design and implement employee-friendly policies with minimum resistance. It also gives the employees a sense of belonging and commitment to the organization and ensures that the capabilities of workers are properly utilized and that they are able to make significant contribution to the effectiveness and economic welfare of the organization Thus, effective participation enable the enterprise to make use of its manpower for the maximum achievement of its declared objectives (Pylee, 1995). The main objective of this study is to examine the implementation of concept of workers participation in management and perception of employees toward the management of H. P. State Electricity Board.

\section{Review of Literature}

Over the years there have been several studies that looked into the role of workers played in the management of organization. Heller and Yakal (1969) stressed that effective functioning of workers participation scheme depend upon the amount of influence leaders allow to their subordinates in decision making processes which are very sensitive to situational variables and environment. It is observed that workers' participation should be given more say in the joint decisions of lower and middle management levels in accordance with the sensitivity of issues concerning work, labour or organization as a whole. 
Frederick and Kenneth (1973) opined that proper and effective implementation of participative management program had not only provided employees certain opportunities to play an active role in planning, co-coordinating and controlling their own work which makes work more meaningful and relevant but also helps in integrating individual goals with organization goals. Pylee (1975) studied emergence of the scheme of workers' participation in decision-making and the extent of its implementation in our country, It is argued that to make workers participation a reality, managerial Attitude toward workers has to be humanalized and proper education and training on participation is inevitable.

Dholkia (1978) brought forth the fact that effective functioning of joint management councils resulted in accelerating production rate and helped in maintaining peaceful and amicable labour management relations both at the shop-floor and at unit level. Sampath (1979) highlighted the importance of delegation of power, span of control, determination of responsibility and authority and power reporting system which forms the basis of creation of an efficient organizational structure. Wendell (1998) focused on the circumstances under which employee participation is effective, employee support for participative approaches, study action, teams total quality management and legal aspects of employee involvement programmes. Sundaray (2007) made an attempt that the changing paradigm of human resource practices and its impact on trade unions regulate the relationship between the employees, and the employers, collective bargaining and workers participation in management are the methods, which reduces the rate of industrial disputes. Bansal (2007) is of this view that workers' participation is increasingly becoming an integral part of management study for developing and sustaining competitive advantage. Knowledge resource has become a vital asset in most of the organizations and therefore attracting, retaining, developing and effectively utilizing human talent has a direct impact on the profitability and growth of the organization.

Srimannarayana (2009) made an attempt to study the role of workers prevailing in the organization in India. The study reveals that the organizations in manufacturing sector could provide better workers' participation in comparison to the organizations dealing in service and technology sector. The author further says that the earlier studies and the present studies shows that overall workers involvement in the organization has improved marginally over a period of time. It is fundamental truth that the workers are the most important assets in the organizations. Workers are pivotal variable without which the inanimate assets are worthless. Workers' participation has gained a considerable importance both in developing and developed countries of the world. In India a good number of industrial and commercial organizations have realized that for the better functioning of management in any sector of the economy ultimately depend upon the effective management of the human resource. Human resource management is the backbone of every organization. Human resource is the only alive factor which put the other nonlive resources into action. Workers' participation plays an important role in service sector because service sector has to constantly deal with people. To deal with workers, the need of workers' participation in the organization is felt. It is a new and emerging area of knowledge that has attached the researchers in social science. Various studies reviewed above provide valuable insights, but still there are a large number of gaps in the available literature. Hence, the present study which is primary and empirical is fully justified.

\section{Methodology}

The study is based on both secondary as well as primary data. Secondary data have been collected from various published and unpublished sources like annual report of the Board, annual report of the H.P. Government, Economic Survey of the Government, and website of H.P. State Electricity Board. Various techniques such as questionnaires, interviews, discussions, observations, and sampling have been used for collection of primary data. To examine the role of workers in the management of H.P State Electricity Board, officers and non-officers are taken into account. The total number of employees in the organization is 2000 (approx.). 10\% sample was taken of the concerned categories of respondents on the basis of stratified random sample method. Employees were given a questionnaire covering issues ranging from specific to general aspects of workers' participation in management, coupled with personal interviews with the respondents. Observation method also helped in getting insight into different problems. To know the opinion of respondents regarding different statements a five point, three point and two point scale was used. 


\section{Findings of the Study}

Role of trade Unions in Management: Table 1 reveals that respondents who belongs to the age group of up to $25,4(40)$ are satisfied with the role played by the trade unions whereas $6(60)$ are not satisfied with it. Employees whose age group is 25 to 50, 83 (68.6) are satisfied as compare to 38 (31.4) who are not satisfied.

Table1: Respondents views about the role played by trade unions on the basis of age group

\begin{tabular}{lllll}
\hline S/N & Age group & Respondents views & Total \\
\hline & & (Yes) & $\mathbf{( N o )}$ & \\
1. & Up to 25 years & $4(40)$ & $6(60)$ & $10(100)$ \\
2. & 25 to 50 years & $83(68.6)$ & $38(31.4)$ & $121(100)$ \\
3. & 50 and above & $39(56.5)$ & $30(43.5)$ & $69(100)$ \\
& Total & $126(63)$ & $74(37)$ & $200(100)$ \\
\hline
\end{tabular}

$\chi^{2}=5.137 \mathrm{df}=2 \mathrm{P}>0.05$ contingency coefficient $=.158$

Source: Data collected through questionnaire. Note: Figures in parenthesis indicates percentage.

In the category of above fifty age group 39 (56.5) say that they are satisfied and the remaining 30, (43.5) say they are not satisfied with the role played by the trade unions. The $\chi^{2}$ test shows insignificant relationship between the two variables. The contingency value is more than zero, which shows that there is association between age and the trade unions's role. So a conclusion can be drawn that most of the employees are satisfied with the role played by trade unions.

Perception of Workers towards management decision making process: Table 2 shows that the respondents whose age lies between 25-50 years are highest in percentage (12.4) who say that decisions taken solely by management are always right followed by those whose age is up to 25 years (10) and above 50 years (9.5). On the other hand respondents whose age is more than fifty (58) are against it and (37.7) are of the views that workers should be consulted in the decision making process. In all (9.5) are in favour and (44) are against it, whereas (46.5) are of the opinion that workers' participation in management is the best way to take any decisions.

Table2: Respondents opinion about workers' participation in Decision Taken Solely by Management on the basis of age group

\begin{tabular}{llllll}
\hline & & \multicolumn{3}{c}{ Respondents views } & \multirow{2}{*}{ Total } \\
\cline { 3 - 5 } S/N & Age group & Always right & $\begin{array}{c}\text { Always not } \\
\text { right }\end{array}$ & $\begin{array}{c}\text { Workers should be } \\
\text { consulted }\end{array}$ & \\
\hline 1. & Up to 25years & $1(10)$ & $4(40)$ & $5(50)$ & $10(100)$ \\
2. & 25 to 50years & $15(12.4)$ & $44(36.4)$ & $62(51.2)$ & $121(100)$ \\
3. & 50 and above & $3(4.3)$ & $40(58)$ & $26(37.7)$ & $69(100)$ \\
& Total & $19(9.5)$ & $88(44)$ & $93(46.5)$ & $200(100)$ \\
\hline
\end{tabular}

$\chi^{2}=9.965 \mathrm{df}=4 \mathrm{P}<0.05$ contingency coefficient $=.218$

Source: Data collected through questionnaire. Note: Figures in parenthesis indicate percentage.

The value of $\chi^{2}$ is higher than the table value at $5 \%$ level of significance. Hence hypothesis is rejected. It means that there is significant difference in the opinion of different age group respondents. The value of contingency coefficient .218 also supports the above view point. Consequently it can be said that majority of employees are of the opinion that workers should be consulted in decision making process by the management.

Workers' Opinion about Management: Table 3 reveals the employees views relating to management committee members, in which the mean value of the respondents opinion is slightly more than the standard average i.e. three at five point scale. The standard variation of the opinion is 1.1558 and skewness is -.552, which reveals that the views of the respondents are scattered more towards the higher side from the average mean. The negative value of kurtosis shows that the distribution of the responses is platykurtic. $\chi^{2}$ test of goodness of fit rejects the Ho at $5 \%$ level of significance it shows that distribution of 
the opinion is not equal. So it can be concluded that the employees are disagree with the statement that management committee members are honest. As far as decision taken by the management, the mean value of the respondents is just below the average mean, which is three at 5 point scale. The variation in the opinion and skewness is noted 1.0864 and -.235 respectively. It shows that the opinion of the respondents is dispersed neither higher side nor lower side. It is just near the average mean. The calculated value of kurtosis shows that the distribution of the views is platykurtic. Chi square test of goodness of fit rejects the null hypothesis at five percent level of significance, which further shows that the distribution of the opinion is not equal. Therefore it can be concluded that management of the Board does not take the decisions timely. So far action orientation is concerned $37.5 \%$ respondents agree while $29 \%$ strongly disagree and $19.5 \%$ disagree. Only three percent employees strongly agree whereas $11 \%$ don't know about it.

Table 3: Respondents Attitude toward Management

\begin{tabular}{|c|c|c|c|c|c|c|c|c|c|c|c|c|c|}
\hline$\frac{z}{n}$ & $\frac{2}{\frac{2}{0}}$ & 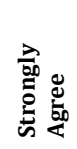 & 递 & 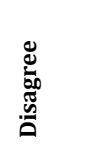 & 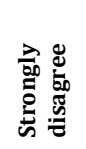 & 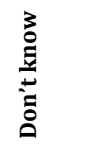 & 푱 & $x$ & 0 & ஸे & 5 & $\tilde{x}$ & $\begin{array}{l}\stackrel{9}{\Xi} \\
\stackrel{\pi}{\supset} \\
2\end{array}$ \\
\hline 1. & $\begin{array}{l}\text { The management } \\
\text { committee } \\
\text { members are } \\
\text { honest }\end{array}$ & $\begin{array}{l}12 \\
(6)\end{array}$ & $\begin{array}{l}63 \\
(31.5)\end{array}$ & $\begin{array}{l}81 \\
(40.5)\end{array}$ & $\begin{array}{l}7 \\
(3.5)\end{array}$ & $\begin{array}{l}37 \\
(18.5)\end{array}$ & $\begin{array}{l}200 \\
(100\end{array}$ & 3.03 & 1.1558 & -.522 & -.513 & $\begin{array}{l}102.3 \\
0\end{array}$ & $<0.05$ \\
\hline 2. & $\begin{array}{l}\text { Take timely } \\
\text { decision }\end{array}$ & $\begin{array}{l}6 \\
(3)\end{array}$ & $\begin{array}{l}79 \\
(39.5)\end{array}$ & $\begin{array}{l}3 \\
(18.5)\end{array}$ & $\begin{array}{l}60 \\
(30)\end{array}$ & $\begin{array}{l}18 \\
(9)\end{array}$ & $\begin{array}{l}200 \\
(100)\end{array}$ & $\begin{array}{l}2.97 \\
5\end{array}$ & 1.0568 & -.235 & -1.127 & 89.25 & $<0.05$ \\
\hline 3. & $\begin{array}{l}\text { They are action } \\
\text { oriented }\end{array}$ & $\begin{array}{l}6 \\
(3)\end{array}$ & $\begin{array}{l}75 \\
(37.5)\end{array}$ & $\begin{array}{l}39 \\
(19.5)\end{array}$ & $\begin{array}{l}58 \\
(29)\end{array}$ & $\begin{array}{l}22 \\
(11)\end{array}$ & $\begin{array}{l}200 \\
(100)\end{array}$ & $\begin{array}{l}2.92 \\
5\end{array}$ & 1.1070 & -.210 & 1.129 & 75.75 & $<0.05$ \\
\hline 4. & $\begin{array}{l}\text { Proper } \\
\text { supervision of } \\
\text { overall activities of } \\
\text { the Board }\end{array}$ & $\begin{array}{l}12 \\
(6)\end{array}$ & $\begin{array}{l}68 \\
(34)\end{array}$ & $\begin{array}{l}36 \\
(18)\end{array}$ & $\begin{array}{l}6 \\
(3.5)\end{array}$ & $\begin{array}{l}23 \\
(11.5)\end{array}$ & $\begin{array}{l}200 \\
(100\end{array}$ & $\begin{array}{l}2.92 \\
5\end{array}$ & 1.1602 & -.067 & -1.120 & 57.85 & $<0.05$ \\
\hline 5. & $\begin{array}{l}\text { Conversant with } \\
\text { the knowledge } \\
\text { about Board and } \\
\text { its principles }\end{array}$ & $\begin{array}{l}6 \\
(3)\end{array}$ & $\begin{array}{l}86 \\
(43)\end{array}$ & $\begin{array}{l}25 \\
(12.5)\end{array}$ & $\begin{array}{l}59 \\
(29.5)\end{array}$ & $\begin{array}{l}24 \\
(12)\end{array}$ & $\begin{array}{l}200 \\
(100)\end{array}$ & $\begin{array}{l}2.95 \\
5\end{array}$ & 1.1531 & -.269 & -1.267 & $\begin{array}{l}102.8 \\
5\end{array}$ & $<0.05$ \\
\hline 6. & $\begin{array}{l}\text { Management } \\
\text { committee are } \\
\text { well aware about } \\
\text { rules and } \\
\text { responsibilities }\end{array}$ & $\begin{array}{l}8 \\
(4)\end{array}$ & $\begin{array}{l}88 \\
(44)\end{array}$ & $\begin{array}{l}28 \\
(14)\end{array}$ & $\begin{array}{l}62 \\
(31)\end{array}$ & $\begin{array}{l}14 \\
(7)\end{array}$ & $\begin{array}{l}200 \\
(100)\end{array}$ & $\begin{array}{l}3.07 \\
0\end{array}$ & 1.0914 & -.281 & 1.165 & $\begin{array}{l}115.8 \\
0\end{array}$ & $<0.05$ \\
\hline
\end{tabular}

Source: Data collected through questionnaire. Note: Figures in parenthesis indicates percentage.

Mean value which is 2.925 less than the standard average supports it. The standard deviation and skewness is recorded 1.1070 and -.21 , which shows that the opinion is scattered slightly more towards upper side. While applying $\chi^{2}$ test of goodness of fit it rejects the hypothesis at $5 \%$ level of significance with the inference that management is not action oriented. Therefore it is clear from the above analysis that management of the electricity Board is not action oriented. Regarding the proper supervision of overall activities of the Board, it is noticed that the mean value of the respondents is less than the standard average i.e. three at five point scale. It indicates that the opinion of the employees is scattered towards the lower side from the average mean. Standard deviation and skewness is noted 1.1602 and .067 respectively. The calculated value of kurtosis shows that the distribution of the responses is platykurtic. Further applying chi square test of goodness of fit it rejects the null hypothesis at $5 \%$ level of significance, which also indicates that distribution of opinion is unequal. Conclusion is that large number of employees disagree with the statement that management takes proper supervision of overall activities of the Board.

As is the case of knowledge of the Board and its principles analysis shows that $43 \%$ respondents agree, $12.5 \%$ disagree while $29.5 \%$ strongly disagree. The mean value of the opinion is less than the standard average, which shows that the opinion of respondents is dispersed more towards lower side from the average mean. The variation of the opinion and skewness is recorded 1.1531 and -.269 respectively. The negative value of kurtosis depicts that distribution of the opinion is platykurtic. The calculated value of $\chi^{2}$ is much more than the table value at five percent level of significance and rejects the null hypothesis, which mean that employees are of the opinion that members of the management are not much conversant with the knowledge of the Board and its principles. So far as management committee's awareness about rules and responsibilities is concerned majority of respondents are agree with it. The 
mean value which is 3.070 more than the average score support it. The standard deviation of the opinion of respondents is 1.0914 and skewness is-.281. It shows that the opinion of respondents is scattered more toward higher side from the mean standard.

The negative value of kurtosis shows that the distribution of the responses is platykurtic. The value of chi square recorded 115.80 which is more than the table value at $5 \%$ level of significance and rejects the null hypothesis. It further shows that distribution of opinion is unequal. Therefore the analysis shows that majority of the employees of the electricity Board agree with the statement that management committee are well aware of the rules and responsibilities of the Board.

Workers' Opinion about Various Personnel Policies

\begin{tabular}{llll}
\multicolumn{4}{l}{ Table 4: } \\
\hline S/N & Nature of Responses & No of respondents & \% age \\
\hline 1. & Setting up the plans & 56 & 28 \\
2. & Fixation of production targets & 14 & 7 \\
3. & Hours of work & 23 & 11.5 \\
4. & Recruitment & 20 & 10 \\
5. & Wage/salary & 50 & 25 \\
6. & Selection & 8 & 4 \\
7. & Training & 5 & 2.5 \\
8. & Promotion & 11 & 5.5 \\
9. & Safety measure & 13 & 6.5 \\
10. & Others & 0 & 0 \\
& Total & 200 & 100 \\
\hline
\end{tabular}

$\chi^{2} 121.3 \mathrm{df}=8 \mathrm{P}<0.05$

Source: Data collected through questionnaire. Note: Figures in parenthesis indicate percentage.

It is clear from the table 4 that $25 \%$ employees are of the views that workers participation sought in the area of wage and salary determination, $28 \%$ says it should be for the setting up of the plans, $11 \%$ hours of work, $10 \%$ for recruitment, $7 \%$ for fixation of product $4 \%$ for selection of employees. $6.5 \%$ respondents say that participation of workers is necessary in the field of safety measure, $2.5 \%$ and $5.5 \%$ says it should be in the area of training and promotions respectively. While using $\chi^{2}$ test of goodness of fit, it rejects the null hypothesis at $5 \%$ level of significance. It indicates that opinion of respondents is not distributed equally. Accordingly it can be said that most of the employees are of the view that workers participation in management should be sought in the area of setting up of the plans and determination of wage and salary structure.

Perception towards Workers' Participation in Management: Table 5 reveals that the mean value of the opinion of respondents regarding maintaining better industrial relations is more than the standard score i.e. three at five point scale. It reveals that their opinion is scattered more towards upper side. The variation in the opinion of respondents is recorded .8714 and skewness is noted .052. It also indicated that the opinion is dispersed higher side from the average score. The calculated value of kurtosis supports that distribution of the opinion of respondents is scattered towards higher side. The value of $\chi^{2}$ is much greater than the table value at $5 \%$ level of significance. Hence hypothesis is rejected. It further shows that distribution of the opinion is unequal. Therefore conclusion can be made from the above analysis that majority of respondents (47.5\%) agree to a moderate extent and $22 \%$ to a high extent, while $26.5 \%$ employees agree to some extent, one \% employees go against it. 
Table 5: Respondents Opinion about Workers' Participation in Management

\begin{tabular}{|c|c|c|c|c|c|c|c|c|c|c|c|c|c|}
\hline S/N & Variables & $\begin{array}{l}\text { To high } \\
\text { Extent }\end{array}$ & $\begin{array}{l}\text { To } \\
\text { moderate } \\
\text { extent }\end{array}$ & $\begin{array}{l}\text { To } \\
\text { Some } \\
\text { extent }\end{array}$ & $\begin{array}{l}\text { Don't } \\
\text { know }\end{array}$ & $\begin{array}{l}\text { Not at } \\
\text { all }\end{array}$ & Total & $\mathbf{X}$ & $\sigma$ & Sk & KT & $\mathrm{X}^{2}$ & P. value \\
\hline 1. & $\begin{array}{l}\text { Maintaining } \\
\text { better } \\
\text { industrial } \\
\text { relation }\end{array}$ & $\begin{array}{l}44 \\
(22)\end{array}$ & $\begin{array}{l}95 \\
(47.5)\end{array}$ & $\begin{array}{l}53 \\
(26.5)\end{array}$ & $\begin{array}{l}6 \\
(3)\end{array}$ & $\begin{array}{l}2 \\
(1)\end{array}$ & $\begin{array}{l}200 \\
(100)\end{array}$ & 3.88 & .8714 & .052 & 2.344 & 211.72 & $\mathrm{P}<0.05$ \\
\hline 2. & $\begin{array}{l}\text { Higher } \\
\text { productivity }\end{array}$ & $\begin{array}{l}47 \\
(23.5)\end{array}$ & $\begin{array}{l}99 \\
(49.5)\end{array}$ & $\begin{array}{l}49 \\
(24.5)\end{array}$ & $\begin{array}{l}3 \\
(1.5)\end{array}$ & $\begin{array}{l}2 \\
(1)\end{array}$ & $\begin{array}{l}200 \\
(100)\end{array}$ & 3.93 & .7926 & -547 & .724 & 160.6 & $\mathrm{P}<0.05$ \\
\hline 3. & $\begin{array}{l}\text { Job } \\
\text { satisfaction }\end{array}$ & $\begin{array}{l}45 \\
(22.5)\end{array}$ & $\begin{array}{l}99 \\
(49.5)\end{array}$ & $\begin{array}{l}53 \\
(26.5)\end{array}$ & $\begin{array}{l}3 \\
(1.5)\end{array}$ & 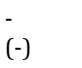 & $\begin{array}{l}200 \\
(100)\end{array}$ & 3.93 & .7402 & 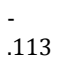 & -.625 & 92.88 & $\mathrm{P}<0.05$ \\
\hline 4. & $\begin{array}{l}\text { Better } \\
\text { discipline }\end{array}$ & $\begin{array}{l}43 \\
(21.5)\end{array}$ & $\begin{array}{l}95 \\
(47.5)\end{array}$ & $\begin{array}{l}58 \\
(29)\end{array}$ & $\begin{array}{l}4 \\
(2)\end{array}$ & 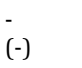 & $\begin{array}{l}200 \\
(100\end{array}$ & 3.89 & .7581 & $\begin{array}{l}- \\
.084\end{array}$ & -.653 & 85.08 & $\mathrm{P}<0.05$ \\
\hline 5. & $\begin{array}{l}\text { Smooth } \\
\text { functioning }\end{array}$ & $\begin{array}{l}48 \\
(24)\end{array}$ & $\begin{array}{l}87 \\
(43.5)\end{array}$ & $\begin{array}{l}63 \\
(31.5)\end{array}$ & $\begin{array}{l}2 \\
(1)\end{array}$ & $(-)$ & $\begin{array}{l}200 \\
(100)\end{array}$ & 3.91 & .7674 & .029 & -.991 & 76.92 & $\mathrm{P}<0.05$ \\
\hline 6. & $\begin{array}{l}\text { Increase } \\
\text { workers' } \\
\text { morale }\end{array}$ & $\begin{array}{l}57 \\
(28.5)\end{array}$ & $\begin{array}{l}95 \\
(47.5)\end{array}$ & $\begin{array}{l}44 \\
(22)\end{array}$ & $\begin{array}{l}2 \\
(1)\end{array}$ & $(-)$ & $\begin{array}{l}200 \\
(100)\end{array}$ & 4.03 & .7664 & $\begin{array}{l}- \\
.313\end{array}$ & -.533 & 84.52 & $\mathrm{P}<0.05$ \\
\hline 7. & $\begin{array}{l}\text { Better } \\
\text { quality }\end{array}$ & $\begin{array}{l}38 \\
(19)\end{array}$ & $\begin{array}{l}96 \\
(48)\end{array}$ & $\begin{array}{l}55 \\
(27.5)\end{array}$ & $\begin{array}{l}11 \\
(5.5)\end{array}$ & $\overline{(-)}$ & $\begin{array}{l}200 \\
(100)\end{array}$ & 3.81 & .8064 & $\begin{array}{l}- \\
.269\end{array}$ & -.382 & 76.12 & $\mathrm{P}<0.05$ \\
\hline 8. & $\begin{array}{l}\text { Create } \\
\text { interest } \\
\text { among } \\
\text { workers }\end{array}$ & $\begin{array}{l}60 \\
(30)\end{array}$ & $\begin{array}{l}87 \\
(43.5)\end{array}$ & $\begin{array}{l}49 \\
(24.5)\end{array}$ & $\begin{array}{l}4 \\
(2)\end{array}$ & $(-)$ & $\begin{array}{l}200 \\
(100)\end{array}$ & 4.02 & .8018 & $\begin{array}{l}- \\
.213\end{array}$ & -.672 & 136.7 & $\mathrm{P}<0.05$ \\
\hline 9. & $\begin{array}{l}\text { Develops } \\
\text { the workers } \\
\text { personality }\end{array}$ & $\begin{array}{l}49 \\
(24.5)\end{array}$ & $\begin{array}{l}93 \\
(46.5)\end{array}$ & $\begin{array}{l}45 \\
(22.5)\end{array}$ & $\begin{array}{l}11 \\
(5.5)\end{array}$ & $\begin{array}{l}2 \\
(1)\end{array}$ & $\begin{array}{l}200 \\
(100)\end{array}$ & 3.88 & .8772 & $\begin{array}{l}- \\
.621\end{array}$ & .271 & 130 & $\mathrm{P}<0.05$ \\
\hline 10. & $\begin{array}{l}\text { Eliminating } \\
\text { wastage }\end{array}$ & $\begin{array}{l}24 \\
(12)\end{array}$ & $\begin{array}{l}26 \\
(13)\end{array}$ & $\begin{array}{l}42 \\
(21)\end{array}$ & $\begin{array}{l}91 \\
(45.5)\end{array}$ & $\begin{array}{l}17 \\
(8.5)\end{array}$ & $\begin{array}{l}200 \\
(100)\end{array}$ & 2.75 & 1.1605 & .647 & -.559 & 89.65 & $\mathrm{P}<0.05$ \\
\hline
\end{tabular}

Source: Data collected through questionnaire. Note: Figures in parenthesis indicates percentage.

Thus it is clear from the analysis that workers participation in management maintains better industrial relations. It is inferred from the table about the higher productivity that large chunk of respondents agree to a moderate extent and $23.5 \%$ to a high extent, while $24.5 \%$ to some extent. The mean value of the opinion is 3.93 which is more than the standard score. The variation in the opinion is .7926 and skewness is -.547, which shows that the opinion of employees is dispersed higher side. The value of kurtosis also supports it. While applying $\chi^{2}$ test of goodness of fit it rejects the null hypothesis at five percent level of significance, which further shows that distribution of opinion is unequal. Therefore it is clear from the above analysis that workers participation in management increases the productivity of the organization. It is observed about the job satisfaction and better discipline that mean value of the opinion of respondents is more than the standard average. Their variation is .7402 and .7581. The skewness is noted -.113 and -.084 respectively, which shows that the opinion of respondents is scattered more towards higher side. The value of kurtosis further indicates that the distribution of the responses is platykurtic. The calculated value of $\chi^{2}$ test is more than the table value at $5 \%$ level of significance in both cases, hence the Ho is rejected. Thus conclusion can be made that workers participation in management increases the job satisfaction and maintain better discipline in the organization. Analysis also shows that the majority of the employees agree to a moderate extent and few go against it.

It is analyzed from the table, about the smooth functioning and increase in the workers' morale, that the mean value of the opinion of respondents is more than the standard average i.e. 3 at 5 point scale. It shows that the opinion of respondents is scattered more towards upper side from the average score. The variation in their opinion is recorded .7674 and .7664, while skewness observed is .029 and -.313 respectively. It further reveals that opinion of respondents is scattered more towards the higher side. The kurtosis in both the cases indicates that distribution of the responses is platykurtic. The calculated value of chi square in both cases is more than the table value at $5 \%$ level of significance, which rejects the null hypothesis with the inference that distribution of the opinion is not equal. Therefore it is concluded that a large number of respondents are of the opinion that workers' participation in management increases the workers' morale and smooth functioning of the organization. 
Employees' opinion regarding better quality and their views about creating interest among workers is that the mean value of the opinion of respondents is more than the average score i.e. three at five point scale. The standard deviation in their opinion is .8064 and .8018 , while skewness is noted -.269 and -.213 respectively. It reveals that the opinion of respondents is dispersed more towards the upper side from the standard score. The kurtosis in both the cases shows that distribution of the responses is platykurtic. While using $\chi^{2}$ test of goodness of fit it rejects the Ho at $5 \%$ level of significance in both cases. It further shows that opinion of respondents is unequal. Thus the conclusion can be made from the above analysis that workers participation in management can provide better quality and create interest among the workers of the organization. With regard to the development of the personality of workers, the calculated value of mean is higher than the standard score. The variation in their opinions works out to be .8772 and the skewness emerges as .621.The value of kurtosis, further, supports the aforesaid findings. The $\chi^{2}$ test of goodness of fit concludes by rejecting the null hypothesis at $5 \%$ level of significance and indicates that the distribution of the workers' opinion is unequal. The findings state that, $46.5 \%$ of the respondents agree with the hypothesis to a moderate extent, $24.5 \%$ to a high extent, $22.5 \%$ to some extent, $1 \%$ do not agree at all and $5.5 \%$ have no opinion on the statement. Thus, it can be stated that the majority opinion held by the respondents is that the participation of the workers in management positively impacts the development of their personality.

The data shows that the mean value of the opinion of the respondents on reducing wastage of resources is located at three on a five-point scale. The variation in their opinion is 1.1605, and the skewness is calculated at .647, that is lower than the average mean. Kurtosis indicates that the distribution of the responses is platykurtic. The calculated value of chi square is higher than the table value at $5 \%$ level of significance. Thus, it may be concluded that the hypothesis is not proven as $45.5 \%$ of the respondents, do not correlate the participation of the workers in management with the reduction of available resources, while $8.5 \%$ have no opinion on this.

Management Behavior towards Employees: It is observed from the table 6 that employees whose service is up to 10 years are 20, out of these 6 (30) say that behaviour of management is cordial and 14 (70) says it is not cordial. Similarly the respondents having a service of 10 - 20 years 6 (11.5) says it very cordial, 16 (30.8) cordial and 30 (57.5) not cordial. Likewise the respondents of third category i.e. having a service of 20 - 30 years 8 (9.6) says it very cordial, 27 (32.6) cordial and 48 (57.8) not cordial. The employees of last category whose service is above thirty years 20 (44.4) say behaviour of management is cordial.

Table 6: Classification of Respondents on the Basis of Years of Service and their views regarding the behaviour of Management

\begin{tabular}{|c|c|c|c|c|c|}
\hline \multirow{2}{*}{$\mathrm{S} / \mathrm{N}$} & \multirow{2}{*}{ Years of service } & \multicolumn{3}{|c|}{ Nature of responses } & \multirow{2}{*}{ Total } \\
\hline & & Very cordial & Cordial & Not cordial & \\
\hline 1. & Less than 10 years & $-(-)$ & $6(30)$ & $14(70)$ & $20(100)$ \\
\hline 2. & $10-20$ years & $6(11.5)$ & $16(30.8)$ & $30(57.7)$ & $52(100)$ \\
\hline 3. & 20-30 years & $8(9.6)$ & $27(32.6)$ & $48(57.8)$ & $83(100)$ \\
\hline \multirow[t]{2}{*}{4.} & Above30 years & $4(8.9)$ & $20(44.4)$ & $21(46.7)$ & $45(100)$ \\
\hline & Total & $18(9)$ & $69(34.5)$ & $113(56.5)$ & $200(100)$ \\
\hline
\end{tabular}

The calculated value of $\chi^{2}$ is less than the table value at $5 \%$ level of significance. Hence the null hypothesis is accepted with the inference that there is insignificant relationship in the opinion of respondents. The contingency coefficient depicts that there is negligible dependency between the years of service of respondents and of the management. So, the above analysis leads to the conclusion that a majority of employees of the organization are not satisfied with the behaviour of the management. 


\section{Conclusion}

Workers' participation in management has assumed great importance these days because it reduces industrial unrest and helps in dispelling employees' misunderstandings about the outlook of management in industry. The organization is giving utmost importance to the workers' participation in management. The organization has been seen to practice sound participative mechanism. There exists a healthy sign of team spirit and co-operation among the employees in the organization. The employees seem to understand and co-operate with each other in the organization. Workers' participation in management may reduce alienation or increase personal fulfillment of workers. It also influences efficiency in various direct and indirect ways. Careful measurement and calculation are required to assess the net effect of participation upon efficiency and economic factor.

The workers' participation in management of H.P. State Electricity Board has increased the total amount of control exercised over the events in the Boards, so the workers gained additional powers without any reduction in management powers. Interpersonal relationship between management and employees is satisfactory. The attitude of employees towards management is not satisfactory because they are of the opinion that management does not take the decision timely and are not action oriented. Most of the employees are of the view that workers' participation in management should be sought in the area of setting up of plans and determination of wage and salary structure. Majority of the employees of the organization are not satisfied with the behaviour of the management. Moreover management takes proper supervision of overall activities of the organization, and work oriented behaviour is encouraged which gives the employees proper direction to channelize their efforts. The study shows that the organization cares a lot for the quality of work life that the employees have in the organization. The management of the Board should create a channel of effective communication between each worker and the management and delegate powers to the subordinates for which actual competence should be the real base of the authority. Hence, there should be a technique to ensure the effective involvement of all the workers in the management of Board. Seminars, conferences, and extensive workers' education programmes let the workers' be prepared to share authority and leadership for making contribution to the corporate objective.

\section{References}

Bansal, P. C. (2007). Organizational Culture and Employee's Morale. Indian Journal of Industrial Relations, 43(2): 291-295.

Dholkia, J. (1978). Workers' Participation in Management: A case study of Gujarat. The Indian Economic Journal, 20(4): 231-236.

Frederick, B. C. and Kenneth, S. T. (1973). Participative Management-A Practical Experience. Lok Udyog, $7(1): 35-39$.

Heller, F. and Yakal G. (1969). Participation: Managerial Decision making and Situational Variables. Organization Behavior and Human Performances, USA: 227-241.

Michael, V. P. (1991). Industrial Relations in India and Workers Involvement in Management, Himalaya Publishing House: Delhi 279-303.

Pylee, M. V. (1975). Workers Participation in Management, N.V. Publications: 191-214.

Pylee, M. V. (1995). Workers Participation in Management-Myth and Reality. N.V. Publication: New Delhi.

Sampath, J. (1979). Program on Personnel Management. Tamil Nadu Journal of Cooperation, 29(2): 43-46.

Sundaray, B. K. (2007). Human Resource Management, A book review. The Indian Journal of Industrial Relations, 43(2): 296-300.

Srimannareyana, M. (2009). Measurement of Human Resource Activities in India. Indian Journal of Industrial Relations, 45(2): 265-276.

Wendell, L. F. (1998). Participative Strategies for Organization Improvement, Human Resource Management, Houghton Mifflin Company: USA 555-586. 